\title{
Peranan Stres Oksidatif Pada Proses Penyembuhan Luka
}

\author{
Handy Arief ${ }^{1^{*}}$, M. Aris Widodo \\ Bagian Ilmu Bedah, Fakultas Kedokteran, Universitas Wijaya Kusuma Surabaya ${ }^{1}$ \\ Fakultas Kedokteran Universitas Brawijaya Malang ${ }^{2}$ \\ *email: handy arief@yahoo.com
}

\begin{abstract}
Abstrak
Penyembuhan luka merupakan proses dinamis yang kompleks yang ditandai dengan serangkaian peristiwa yang terjadi pada hampir semua jenis kerusakan jaringan. Pada fase awal reaksi inflamasi, neutrophil dan makrofag masuk ke dalam jaringan yang mengalami cedera dan sel -sel ini memproduksi Reactive Oxygen Species yang dapat memberikan efek menguntungkan maupun merugikan. Stres oksidatif yang terjadi merupakan kondisi yang menggambarkan ketidak seimbangan antara prooksidan atau radikal bebas dan antioksidan yang berfungsi mempertahankan kondisi terhadap kerusakan jaringan yang terjadi. Jadi stres oksidatif muncul apabila produksi Reactive Oxygen Species yang terjadi melebihi antioksidan yang ada sebagai pertahanan intrinsik. Reactive Oxygen Species dan Reactive Nitrogen Species merupakan komponen yang penting dalam proses penyembuhan luka dan perlu dalam kondisi homeostasis agar tidak menimbulkan stres oksidatif.Yang merupakan komponen utama ROS antara lain superoxide $\left(\mathrm{O}^{\circ}\right)$, hydroxyl radical $\left(\mathrm{OH}^{\circ}\right)$ dan hydrogen peroxide $\left(\mathrm{H}_{2} \mathrm{O}_{2}\right)$, yang termasuk RNS meliputi nitric oxide ( $\left.\mathrm{NO}^{\circ}\right)$, nitrous oxide $\left(\mathrm{NO}_{2}{ }^{\circ}\right)$, nitroxyl anion ( $\mathrm{HNO}$ ) dan peroxynitrite (ONOO-) yang bisa timbul akibat reaksi antara superoxide dan Nitric Oxide. Adanya kondisi yang berlebihan dari $\mathrm{O}_{2}$ - pada luka dan kehadiran NO yang berlebihan dapat meningkatkan timbulnya stres oksidatif sehingga mengganggu proses penyembuhan luka. Stres oksidatif berperan pada fase inflamasi, proliferasi dan remodeling dengan cara meningkatkan angiogenesis dan mempengaruhi sel-sel yang lain termasuk sel endotel dalam mengeluarkan NO. Sehingga strategi dalam mengontrol stres oksidatif dengan cara meningkatkan antioksidan yang bersifat scavenger radikal bebas tehadap pembentukan superoxide yang berlebihan sehingga mencegah terjadinya gangguan pada proses penyembuhan luka.
\end{abstract}

Kata Kunci: Stres Oksidatif, ROS, RNS, Antioksidan, Wound Healing

\section{Rules of Oxidative Stress in Wound Healing}

\begin{abstract}
Wound healing is a complex dynamic process characterized by a series of events that occur in almost all type of tissue damage. In the early phase of the inflammatory response, neutrophils and macrophages enters into the injured tissue and the cells produce reactive oxygen species that can give a beneficial or detrimental effects. Oxidative stress is a condition occurs that shows imbalance between prooxidant or free radical and antioxidant that have a function to maintain the condition of the tissue damage that occurs. So Oxidative stress occurs when the production of Reactive Oxygen Species occurring is higher than the antioxidants existing as an intrinsic defense. Reactive Oxygen Species and Reactive Nitrogen Species are important components in the healing process of wounds and is necessary to be in the state of homeostasis to prevent oksidatif stress. The major components of ROS are superoxide (O2*), hydroxyl radical $\left(\mathrm{OH}^{\circ}\right)$ and hydrogen peroxide $\left(\mathrm{H}_{2} \mathrm{O}_{2}\right)$, which includes $\mathrm{RNS}$ are nitric oxide $\left(\mathrm{NO}^{\circ}\right)$, nitrous oxide $\left(\mathrm{NO}_{2}{ }^{\circ}\right)$, nitroxyl anion ( $\mathrm{HNO}$ ) and peroxynitrite $\left(\mathrm{ONOO}^{-}\right)$which could be form by the reaction between superoxide and nitric oxide. The existence of excessive $\mathrm{O}_{2}$ amount in the wound and the presence of excess NO can increase the incidence of oxidative stress that interfere with wound healing process. Oxidative stress plays a role in the inflammatory phase, proliferation and remodeling phase by increasing angiogenesis and affect other cells including endothelial cells in secreting NO. So the strategy in controlling oxidative stress is by increasing antioxidant level which is a scavenger to free radical excessive superoxide formation so preventing interference with the wound healing process.
\end{abstract}


Keywords: Oxidative Stress, ROS, RNS, Antioxidant, Wound Healing.

\section{PENDAHULUAN}

Penyembuhan luka merupakan proses dinamis yang kompleks yang ditandai dengan adanya serangkaian peristiwa yang terjadi pada hampir semua jenis kerusakan jaringan mulai dari goresan kulit sampai infark miokard yang pada awalnya menimbulkan peradangan sampai nantinya terjadinya perbaikan dari jaringan yang mengalami kerusakan akibat cedera tersebut. Pada fase awal reaksi inflamasi, neutrofil dan makrofag akan masuk ke dalam jaringan yang mengalami cedera atau luka akibat adanya berbagai faktor kemotaktik. Sel-sel ini akan memproduksi Reactive Oxygen Spesies (ROS) yang dapat memberikan efek menguntungkan maupun merugikan pada jaringan sekitarnya. Selain diproduksi oleh neutrophil, ROS yang dapat memberikan efek bakterisidal ini juga diproduksi oleh sel yang sedang mengalami proliferasi serta mempunyai peranan yang penting dalam intraseluler signaling sebagai tanggapan adanya berbagai rangsangan ekstraseluler, sebagai contoh Hidrogen peroksida akan terlihat dalam jumlah terbatas dan menginduksi Vascular Endothelial Growth Factor (VEGF) pada proses penyembuhan luka yang akan terekspresi dalam keratinosit serta mendukung juga peningkatan angiogenesisnya. Sebaliknya produksi ROS yang berlebihan dapat menyebabkan kerusakan jaringan dan mengganggu proses penyembuhan luka. Enzim phosphotyrosine fosfatase dan antioksidan dengan berat molekul rendah seperti glutathione memegang peranan penting dalam regulasi redoks selular terhadap homeostasis seluler yang terjadi karena produksi ROS yang berlebihan dapat mengganggu fungsi komunikasi antar sel dan akhirnya mempengaruhi proses penyembuhan luka. Tubuh sendiri memiliki beberapa sistem antioksidan dan redoks untuk melindungi diri terhadap kerusakan yang ditimbulkan akibat adanya stres oksidatif $(1,2)$.

Pada kondisi yang normal sistem biologis berada dalam keseimbangan antara jumlah oksidan dan antioksidan untuk mencegah timbulnya kerusakan oksidatif. Kemampuan sel dalam mempertahankan homeostasis dengan cara mencegah akumulasi oksidan secara berlebihan disebut sebagai homeostasis redoxs (3). Oksidan sebenarnya memainkan peranan yang penting dalam penyembuhan luka dengan memberikan tanda dan membuat pertahanan terhadap mikroorganisme yang ada. Tetapi oksidan tersebut harus didetoksifikasi terlebih dulu untuk mencegah terjadinya kerusakan pada sel dengan cara mereduksi atau scavenging dan atau dismutasi superoksida anion $\left(\mathrm{O}_{2}{ }^{-}\right)$dan atau peroksida anion $\left(\mathrm{HO}_{2}{ }^{-}\right)$ beserta bentuk protonasinya dengan menggunakan sistem pertahanan antioksidan. Sistem pertahanan antioksidan yang gagal dalam menghilangkan oksidan yang berlebihan akan menimbulkan gangguan dalam homeostasisnya serta menimbulkan stres oksidatif (4).

Adanya bukti yang menyatakan terdapat peranan stres oksidatif dalam patogenesis luka yang sulit sembuh atau luka kronis, maka pada makalah ini perlu dibahas lebih dalam pentingnya peranan stres oksidatif dalam proses penyembuhan luka beserta komponen penyebabnya sebagai strategi dasar pengembangan terapi selanjutnya.

\section{PEMBAHASAN}

\section{Penyebab Stress Oksidatif}

Stres oksidatif adalah kondisi yang menggambarkan adanya ketidakseimbangan antara prooksidan atau radikal bebas dan antioksidan yang berfungsi dalam mempertahankan kondisi terhadap kerusakan jaringan yang terjadi. Jadi stres oksidatif ini muncul apabila produksi ROS atau radikal bebas yang terjadi melebihi antioksidan yang ada sebagai pertahanan intrinsik. Reactive Oxygen Species (ROS) yang merupakan radikal yang sangat reaktif atau molekul yang diproduksi secara intraseluler seperti mitokondria, retikulum endoplasma, peroksisom. ROS juga dapat disebabkan oleh sumber yang berasal dari luar seperti bahan yang mengalami ionisasi, vitamin, atau herbisida dan ROS ini dapat berinteraksi secara biomolekul dengan hasil oksidasi protein berupa residu amino asil dan menyebabkan mutasi pada DNA, serta bereaksi juga dengan peroksidasi lipid untuk memproduksi radikal bebas yang lebih banyak lagi. Kelebihan produksi ROS dalam sel dapat melebihi sistem detoksifikasi seluler yang ada sehingga menyebabkan stres oksidatif. ROS sebenarnya tidak selalu merugikan karena dapat 
bertindak sebagai second messenger dalam sinyal kaskade intraseluler, untuk mempertahankan homeostasis sel dengan lingkungan terdekatnya termasuk proses penyembuhan luka (5). Tetapi pada konsentrasi yang lebih tinggi dapat menimbulkan kerusakan mulai tingkat sel, jaringan hingga kerusakan organ tubuh $(6,7,8)$.

Superoksida merupakan komponen utama dari ROS dan superoksida ini dengan cepat diubah menjadi $\mathrm{H}_{2} \mathrm{O}_{2}$ dan diinduksi oleh Superoxide dismutase (SOD). $\mathrm{H}_{2} \mathrm{O}_{2}$ ini selanjutnya didetoksifikasi oleh enzim katalase menjadi $\mathrm{H}_{2} \mathrm{O}$ dan $\mathrm{O}_{2}$, adanya $\mathrm{Fe}^{2+}$ atau $\mathrm{Cu}^{2+}$ dapat mereduksi $\mathrm{H}_{2} \mathrm{O}_{2}$ menjadi $\mathrm{OH}^{-}$dan $\mathrm{OH}^{\circ}$ yang merupakan radikal hidroksil yang sangat reaktif. $\mathrm{O}_{2}^{-}, \mathrm{H}_{2} \mathrm{O}_{2}$ dan $\mathrm{OH}^{*}$ inilah yang merupakan komponen stres oksidatif yang dapat dilihat pada tabel 1 (4). Selama proses penyembuhan luka sel inflamasi seperti neutrofil, makrofag, sel-sel endotel dan fibroblast menghasilkan superoksida, aktifasi neutrophil dan makrofag ini menghasilkan sejumlah besar superoksida dan turunannya melalui fagocytic isoform NADPH oksidase. Trombin, PDGF dan Tissue Necrosis Factor $\alpha$ (TNF- $\alpha$ ) akan merangsang pelepasan superoksida dari sel endotel sedangkan interleukin 1 (IL-1), TNF- $\alpha$ dan Platelet Activation Factor (PAF) merangsang pelepasan superoksida dari fibroblast. Sel endotel juga dapat menghasilkan $\mathrm{O}_{2}^{-}, \mathrm{H}_{2} \mathrm{O}_{2}$ dan $\mathrm{OH}^{\bullet}$ dalam konsentrasi tinggi pada kondisi iskemik yang umumnya terjadi pada luka (4). ROS bisa dilepaskan dari Nicotinamide Adenine Dinucleotide Phosphate oxidase (NAD $(\mathrm{P}) \mathrm{H})$, xanthine oxidase, lipoxygenase, mitokondria, atau uncoupling synthase Nitric Oxide synthase (eNOS) sel-sel vascular $(4,9)$.

Tabel 1. Komponen utama Stres Oksidatif dan Stres Nitroxidative (4)

\begin{tabular}{ll}
\hline Stress Oksidatif & Stress Nitrooksidatif \\
\hline singlet oksigen & anion peroksinitrit \\
superoksida & asam peroksinitrat \\
radikal hidroksida & nitronium \\
hydrogen peroksida & radikal nitrogen dioksida \\
asam hipoklorats & nitril clorida \\
radikal trioksokarbonat & ion nitrit \\
\hline
\end{tabular}

\section{Peranan Stres Oksidatif pada Proses Penyembuhan Luka.}

Secara fisiologis, fase inflamasi berlangsung antara 4 sampai 6 hari dan terjadi segera setelah luka, pembuluh darah akan menyempit terjadi pengaktifan agregasi platelet sepanjang endotelium. Terputusnya pembuluh darah dan vasokonstriksi ini menyebabkan bertambahnya hipoksia yang diperkuat dengan peningkatan konsumsi oksigen oleh sel-sel yang aktif secara metabolik berkontribusi terhadap penyembuhan luka. Hipoksia merupakan langkah awal pada saat penyembuhan luka dengan meningkatkan aktivitas ROS dan mengaktifkan platelet dan endothelium serta menginduksi sitokin yang akn dilepaskan oleh trombosit, monosit dan sel parenkim seperti growth factor VEGF, TGF- $\beta$, TNF (10).

ROS yang dihasilkan pada stres oksidatif memainkan peranan yang sangat penting dalam proses pembekuan darah yang terjadi pada luka dengan cara menginduksi tissue factor (TF)mRNA. TF yang dikeluarkan akibat adanya kerusakan jaringan akan menginisiasi jalur koagulasi ekstrinsik dan pembentukan selanjutnya akan berasal dari trombin. ROS yang dikeluarkan trombin akan menginduksi TFmRNA dan meningkatkan ketergantungan aktivitas permukaan prokoagulasi TF dalam mempotensiasi siklus trombogenik (pembekuan) pembuluh darah yang rusak. ROS juga terlibat dalam peningkatan platelet dan kolagen. Aktifasi dan agregasi platelet tersebut merupakan hal penting dalam proses pembentukan bekuan darah yang dapat merangsang terjadinya pelepasan berbagai faktor pertumbuhan dan sitokin dalam memulai proses penyembuhan luka. Platelet yang diaktifkan selanjutnya mempotensiasi pembentukan bekuan dengan cara pelepasan ROS dan RNS sehingga meningkatkan ekspresi TF (4).

Berbagai faktor pertumbuhan akan dilepaskan oleh platelet, leukosit dan fibroblast serta bertanggung jawab terhadap penarikan dan aktifasi neutrophil, monosit pada daerah luka yang akan memulai terjadinya angiogenesis dan reepitelisasi. TGF yang dikeluarkan oleh fibroblast dan lekosit akan menginduksi sel-sel dengan cara autokrin untuk menghasilkan sitokin tambahan seperti TNF- $\alpha$, IL-1b dan PDGF yang selanjutnya akan mempotensiasi terjadinya respon inflamasi. PDGF akan mengaktifkan faktor transkripsi Neutrophyl Factor $k B$ (NF-kB) dan macrophage chemoattractant protein-1 dalam merangsang timbulnya respon inflamasi. $\mathrm{H}_{2} \mathrm{O}_{2}$ bertindak sebagai second messenger untuk growth factors seperti PDGF dan TGF sehingga dikatakan $\mathrm{H}_{2} \mathrm{O}_{2}$ sebagai perantara respon inflamasi dari growth 
factors tersebut. Selain itu, ROS dan RNS dapat secara langsung menarik neutrofil sebagai hasil penurunan ROS atau RNS karena pemberian antioksidan seperti thioredoxin dengan cara menekan LPS yang dimediasi oleh adanya leukosit. Macrophage inflammatory protein-1 $\alpha$ (MIP-1 $\alpha$ ), terbukti mempunyai kontribusi dalam penarikan, aktifasi monosit atau makrofag dan neutrophil, stres oksidatif yang terjadi dapat meningkatkan stabilisasi transkripsi, translasi setelah stabilisasi MIP- $1 \alpha$ tersebut. $\mathrm{H}_{2} \mathrm{O}_{2}$ juga memfasilitasi melekatnya neutrofil, monosit pada matriks ekstraseluler dan sel endotel, dengan cara memodulasi ekspresi molekul adhesi leukosit tersebut. Perlekatan ini juga menginduksi ekspresi colony monocyte stimulating factor-1 (CSF-1) yang mendukung keberadaan monosit dan makrofag pada luka tersebut. Sehingga dikatakan ROS dan RNS memegang peranan yang bermakna dalam fase inflamasi suatu penyembuhan luka(4).

ROS juga ternyata membantu dalam proses reepitelisasi dengan cara mengaktifkan ekspresi kolagenase dan memediasi EGF signaling. $\mathrm{H}_{2} \mathrm{O}_{2}$ mengaktifkan Activator Protein 1 (AP-1) yang selanjutnya akan menginduksi ekspresi kolagenase (MMP-1) (11). Kolagenase membantu degradasi matriks ekstraseluler yang selanjutnya membantu dalam migrasi sel yang terkait dengan luka. Satu dua hari setelah cedera, keratinosit akan berproliferasi untuk mendukung kehadirannya pada luka tersebut. $\mathrm{H}_{2} \mathrm{O}_{2}$ juga bertanggung jawab sebagai sinyal terhadap epidermal growth factor (EGF) dalam meningkatkan proliferasi keratinosit $(4,12)$.

Hipoksia akut dan ROS merupakan stimulator yang penting saat terjadinya angiogenesis, keduanya merangsang makrofag, fibroblas, sel endotel dan keratinosit untuk mensintesis VEGF tetapi bila hipoksia ini terjadi secara kronis malahan akan mengganggu mengganggu neovaskularisasi. Hipoksia akan mengaktifkan Hypoxia-inducible factor $-1 \alpha$ (HIF$1 \alpha)$ dan mengikat elemen respon hipoksia yang akan meningkatkan promotor gen dari gen VEGF yang akhirnya akan meningkatkan VEGF dan VEGF ini merupakan faktor pertumbuhan angiogenik utama yang merangsang sel-sel endotel untuk bermigrasi, berkembang biak dan membentuk kapiler baru yang tak terhitung jumlahnya (10).

Angiogenesis dan deposisi matriks yang terjadinya setelah cedera, terlihat sebagai jaringan granulasi yang berupa pembentukan kapiler-kapiler baru dan FGF-2 serta vascular endothelial growth factor (VEGF) yang dikeluarkan pada daerah luka dengan cara merangsang timbulnya angiogenesis dan peningkatan afinitas FGF-2 ke reseptor dan induksi ekspresinya ini di lakukan oleh ROS. $\mathrm{H}_{2} \mathrm{O}_{2}$ dapat menginduksi ekspresi VEGF pada keratinosit selama terjadinya proses penyembuhan luka tersebut. Matriks akan dibentuk oleh molekul yang strukturnya dihasilkan oleh fibroblast dan akan memberikan dukungan dalam pembentukan jaringan granulasi. Matriks ini selanjutnya digantikan oleh cross-linked kolagen yang disintesis oleh fibroblast yang diaktifkan dan $\mathrm{H}_{2} \mathrm{O}_{2}$ akan menginduksi pembentukan kolagen I, III, IV dan segala kejadian persilangannya. Ketika fibroblast menghasilkan dan sekaligus merombak matriks yang kaya akan kolagen, sebagian dari fibroblast ini akan berubah menjadi myofibroblasts yang akan membantu terjadinya kontraksi luka dan ROS berperan dalam perubahan fibroblast menjadi myofibroblasts tersebut. Luka yang mengalami kontraksi akan membantu dalam proses reepitelisasi sehingga lebih cepat membawa tepi luka yang satu ke tepi luka yang lain. Bukti terbaru menunjukan adanya keterlibatan langsung ROS atau RNS pada luka kronis, hal ini dapat dilihat dari peningkatan persentase rasio allantoin asam urat (AUR) yang merupakan biomarker dalam menilai adanya peningkatan stres oksidatif atau stres nitroxidative yang terjadi pada luka kronis. Isoprostanes yang merupakan senyawa seperti prostaglandin dihasilkan oleh radikal bebas yang berasal dari oksidasi asam lemak tak jenuh pada membran fosfolipid, merupakan indikator penting dari stres oksidatif in vivo. Kadar 8-iso prostane ditemukan lebih tinggi pada ulkus vena kronis dibanding dalam cairan luka akut, hal ini menunjukkan adanya aktivitas oksidatif yang lebih besar dalam luka kronis. Terdapat pula peningkatan aktivitas iNOS yang terjadi pada ulkus vena kronis maupun ulkus kaki diabetic dan terdapat deposisi kelebihan zat besi pada kulit penderita yang mengalami ulserasi vena yang menunjukan adanya peningkatan pembentukan radikal bebas melalui reaksi Fenton (4).

Berbagai macam efek yang merusak dari ROS atau RNS dapat dilihat pada luka kronis karena ROS atau RNS yang berlebihan akan menyebabkan inaktifasi epidermal antioksidan enzimatik walaupun terjadi peningkatan ekspresi antioksidan enzimatik pada luka 
tersebut, kondisi ini juga akan menghabiskan kadar antioksidan nonenzimatik yang masih ada pada jaringan luka. Hal ini yang menyebabkan kondisi tersebut berkelanjutan dengan tetap dipertahankannya kehadiran ROS atau RNS pada luka kronis. Stres oksidatif dan stres nitroxidative akan memperpanjang pada masa inflamasi luka kronis karena ROS dan RNS akan merangsang kemotaksis neutrophil, makrofag dan migrasinya serta menginduksi ekspresi molekul adhesi dalam pembuluh kapiler. Efek seluler langsung dari ROS atau RNS meliputi gangguan migrasi, proliferasi dan extra cellular matrix (ECM) yang dihasilkan fibroblast dan keratinosit (4).

Stres nitroxidative dapat meningkatkan kerusakan matriks dan apoptosis pada daerah ulkus, hal ini dapat dilihat dari ekspresi iNOS dan arginase yang meningkat pada penyakit vena kronis dan ulkus diabetes yang mana arginase ini bertanggung jawab terhadap peningkatan matriks, namun karena stres nitroxidative dan aktifitas proteolitik yang tinggi maka justru terjadi banyak penumpukan matriks yang rusak pada ulkus tersebut. Tingginya kadar NO yang diproduksi oleh iNOS akan berinteraksi dengan radikal bebas oksigen yang berasal dari polimorfonuklear (PMN) dan makrofag dalam pembentukan peroxynitrite dan peroxynitrite ini yang menginduksi apoptosis atau nekrosis yang semua ini tergantung konsentrasinya di dalam daerah ulkus tersebut. Keseimbangan aktivitas protease memegang peranan yang penting dalam penyembuhan luka, leukosit yang ada akan melepaskan protease kemudian akan mendegradasi pembentukan matriks sementara dan merombak komponen ECMnya dan memiliki peranan yang penting dalam vasokonstriksi, peningkatan permeabilitas membran, peningkatan koagulasi, adhesi leukosit, kemotaksis, migrasi dan pembunuhan bakteri serta menghilangkan debris jaringan ,merangsang respon inflamasi dan peningkatan aktifitas growth factor. Pada luka akut terdapat protease inhibitor akan mengatur aktifitas protease ini, sehingga terdapat keseimbangan antara aktivitas protease serta antiprotease dalam penyembuhan luka tersebut. Kelebihan oksidan yang terjadi pada luka kronis akan menciptakan ketidakseimbangan antara kadar protease dan antiprotease sehingga terjadi peningkatan protease dan peningkatan penghambatan antiprotease. Masuknya neutrofil yang terus menerus akan menghasilkan ROS atau RNS yang berlebihan sehingga menambah gangguan keseimbangan protease-antiprotease dengan cara menurunkan kadar inhibitor protease, chloramines dan $\mathrm{HOCl}$ mengoksidasi baik macroglobulin $\alpha 2$ dan antiprotease $\alpha 1$ yang akan mengurangi kadar inhibitor protease tersebut. Hasil aktivitas enzim protease yang berlebihan dapat menyebabkan degradasi komponen ECM seperti kolagen, proteoglikan dan hyaluronan sehingga terjadi penyembuhan luka menjadi tertunda. Fibroblast yang memegang peranan yang penting dalam penyembuhan luka dengan cara membentuk kembali molekul matriks ekstraseluler seperti kolagen, juga akan memproduksi mitogens untuk keratinosit, sel endotel dan fibroblast. Pada luka kronis fibroblast mempunyai bentuk yang lebih besar dengan morfologi yang abnormal dan mirip dengan fibroblast yang tua. Salah satu penelitian menunjukkan bahwa ketika fibroblast yang baru terbentuk diinkubasi dengan cairan ulkus vena maka dapat mengurangi kapasitas proliferasinya dan menginduksi diri menjadi fibroblast yang tua. Hal ini menunjukkan bahwa lingkungan mikro ulkus vena mempengaruhi fungsi fibroblast dengan cara menginduksi fibroblast menjadi lebih cepat mengalami penuaan. Hal ini menunjukkan bahwa stres oksidatif yang tinggi pada luka kronis mungkin menjadi faktor penyebab yang mendorong proses penuaan pada fibroblast pada luka kronis, fibroblast yang semakin tua tidak mampu membelah diri walaupun masih aktif secara metabolik tetapi kurang aktif dan terakumulasinya fibroblast ini pada jaringan karena adanya perlawanan terhadap proses apoptosis dengan susunan protein yang berbeda, termasuk peningkatan kadar matriks metalloproteasenya dan sitokin pro-inflamasinya. Pada penelitian dibuktikan stres oksidatif juga mengganggu kontraksi fibroblast bila ditanam dalam media hiperglikemia dan stres oksidatif yang tinggi dapat menghambat migrasi dan proliferasi keratinosit dengan cara pemberian hidrogen peroksida dalam konsentrasi mikromolar sehingga stres oksidatif dianggap sebagai faktor penyebab yang penting dalam timbulnya komplikasi luka diabetes dan stres oksidatif dikatakan dapat menginduksi apoptosis sel-sel keratinosit ketika dikultur dalam media hiperglikemia (4). 


\section{Peranan Antioksidan dalam Terapi Penyembuhan Luka}

Antioksidan merupakan molekul yang mampu menghambat oksidasi dari molekul oksidan, dan oksidasi tersebut merupakan reaksi kimia yang memindahkan elektron dari satu substansi ke agen oksidan $(7,13)$. Pada luka akut maupun luka kronis ekspresi enzimatik antioksidan meningkat tetapi aktifitasnya menurun karena pengaruh stres oksidatif yang tinggi yang menyebabkan berkurangnya antioksidan nonenzimatik dan pengaruh ini akan lebih parah terjadi pada luka kronis dibandingkan luka akut. Suplementasi luka dengan antioksidan akan membantu dalam pencegahan kerusakan akibat oksidasi sel sehingga meningkatkan penyembuhan luka tersebut (4). Sel dilengkapi dengan berbagai antioksidan yang bekerja melalui berbagai macam mekanisme antioksidan, terdapat dua macam antioksidan yaitu antioksidan enzimatik berupa Superoksida dismutase (SOD) merupakan pelindung ekstraseluler terhadap dampak negative $\mathrm{O}_{2}^{-}$, Glutation peroksidase (GPX) dan Glutation reduktase (GRD) yang akan menahan dampak negatif $\mathrm{H}_{2} \mathrm{O}_{2}$, katalase, Glukosa-6 fosfat dehydrogenase (G6PD), sistem sitokrom oksidase dan antioksidan non enzimatik akan mempertahankan membrane sel berupa senyawa yang terbentuk secara in vivo seperti glutation, albumin, transferin/laktoferin/seruloplasmin, ferritin, sistein, bilirubin dan senyawa yang digolongkan mikronutrien esensial seperti karotenoid $(\beta$ karoten), zinc, selenium dan vitamin $A$, vitamin $B$, vitamin $C$, vitamin $K$, vitamin $D$, vitamin $E$ $(7,13)$.

Berdasarkan mekanisme pertahanannya, antioksidan dibedakan atas:

1. Mekanisme pertahanan antioksidan primer/chain breaker/ scavenger antioxidants dengan cara menetralisir radikal bebas dengan mendonasi satu electron yang menjadi radikal bebas yang relatif stabil tetapi dapat dinetralisir oleh antioksidan lainnya contoh: vitamin $\mathrm{E}$, vitamin C, Asam a Lipoat (ALA), CoQ10, flavonoid, asam urat dan bilirubin.

2. Mekanisme pertahanan antioksidan sekunder/ preventive antioxidants bekerja dengan mengikat logam pemicu ROS dan menyingkirkan ROS, contohnya transferrin, laktoferin, seruloplasmin dan albumin.
3. Mekanisme pertahanan tersier dilakukan untuk mencegah penumpukan biomolekul yang telah rusak supaya tidak menimbulkan kerusakan lebih lanjut enzim metionin sulfaoksida reduktase yang akan memperbaiki DNA yang rusak, enzim proteolitik akan memproses protein yang teroksidasi, lipase, peroksidase akan memproses lipid teroksidasi(7).

Berdasarkan kelarutannya, antioksidan dibedakan atas:

1. antioksidan yang larut dalam minyak misalnya vitamin A, vitamin E dan CoQ10

2. antioksidan yang larut dalam air misalnya vitamin $C$ dan glutation, sedangkan Asam $\alpha$ Lipoat (ALA) larut dalam lemak dan air.

Jenis antioksidan juga dapat dibedakan atas

a. Antioksidan alamiah seperti flavonoid, kumarin, asam fenolat, asam linoleat, omega-3, vitamin E, $\beta$-karoten, vitamin C.

b. Antioksidan farmakologis/sintetik seperti probukol, inhibitor xantin oksidase (allopurinol, asam folat), SOD, katalase, NADPH inhibitors (adenosine, calcium channel blockers), antioksidan endogen hasil aktifitas glutation peroksidase (glutation, asetilsistein), inhibitor siklus redoks besi (deferoksmin, apotransferin, seruloplasmin), antiinflamasi nonsteroid, oral antidiabetik (metformin), statin (simvastatin), omeperazole.

Terdapat 2 strategi dalam meredam dampak negative dari oksidan ini yaitu mencegah menumpuknya senyawa oksida dan mencegah rantai reaksi berkelanjutan dengan mengoptimalkan sistem antioksidan (7).

Iskemia kulit merupakan lingkungan yang baik yang dapat menimbulkan stres oksidatif akibat leukosit yang diaktifkan. Pemakaian raxofelast suatu analog vitamin $\mathrm{E}$ yang bersifat hidrofilik yang diberikan untuk luka diabetes, mampu mengurangi stres oksidatif dengan cara mengurangi peroksidasi lipid dan edema. Raxofelast ini kemudian mendorong reepithelisasi, neovaskularisasi, proliferasi fibroblast serta sintesa dan pematangan matriks ekstraseluler. Demikian pula taurin, sebagai formulasi gel kitosan, sudah digunakan sebagai antioksidan untuk meningkatkan reepithelisasi, tensile strength dan produksi kolagen pada luka. Sebagai direct acting antioksidan, taurin secara signifikan dapat mengurangi peroksidasi lipid dan sebagai indirect antioksidan dapat menstabilkan membran plasma. Hal ini 
ISSN 1978-2071 (Print); ISSN 2580-5967 (Online) Jurnal IImiah Kedokteran Wijaya Kusuma 5(2) : 22-29

menunjukkan bahwa pemberian suplemen antioksidan pada luka diabetes dapat melindungi sel-sel tersebut dari stres oksidatif yang dihasilkan akibat kadar glukosa yang tinggi. Ketika fibroblast itu ditumbuhkan dibawah media glukosa yang tinggi maka fibroblast ini menunjukkan penurunan kontraksinya dan tak bereaksi terhadap growth factor yang memacu proliferasi sedangkan keratinositnya lebih rentan terhadap apoptosis. Penambahan glutathion dapat mempertahankan kembali kemampuan fibroblast berkontraksi dan melindungi keratinosit dari apoptosis. Demikian juga penambahan vitamin C, Selenite, vitamin E, karotenoid dan Q10 dapat mengembalikan resistensi fibroblast terhadap rangsangan growth factor akibat kadar glukosa yang tinggi. Beberapa antioksidan seperti vitamin C, katalase, kombinasi antioksidan dan mineral juga telah digunakan untuk meningkatkan penyembuhan. Vitamin C memiliki peranan dalam pembentukan dan mempertahankan kolagen saat penyembuhan luka serta dapat mencegah perdarahan yang berasal dari komponen vaskular jaringan ikat. Vitamin $\mathrm{C}$ juga dapat digunakan untuk memperbaiki keterlambatan penyembuhan luka akibat radiasi. Katalase dapat mendetoksifikasi hidrogen peroksida yang dapat menimbulkan kerusakan parah pada regenerasi sel dan aplikasi topikal katalase dapat meningkatkan penyembuhan jaringan pulpa gigi. Kombinasi vitamin $\mathrm{E}$, sodium pyruvate dan asam lemak telah digunakan untuk meningkatkan penyembuhan pada kondisi normal, laser resurfacing dan luka akibat sistem imun yang tertekan. Sodium pyruvate dan vitamin $\mathrm{E}$ berfungsi sebagai antioksidan, asam lemak tak jenuh berperan sebagai sumber pengganti asam lemak membran yang rusak. Zinc juga berfungsi sebagai antioksidan pada kulit serta memiliki efek yang menguntungkan dalam penyembuhan luka. Pengaruh antioksidannya terkait dengan penggantian redox reactive metals seperti zat besi dan tembaga pada tingkat sel dan ekstraselulernya sehingga dapat mencegah meningkatnya hydroxyl radical serta menginduksi sintesa senyawa metallothionein yang berperan sebagai scavenger radikal bebas (4).

\section{KESIMPULAN}

Stres oksidatif dapat ditimbulkan oleh Reactive Oxygen Species (ROS) dan juga Nitroxidative stress melalui Reactive Nirogen Species (RNS). Stres oksidatif mempunyai efek yang menguntungkan dan efek merugikan bila berlebihan serta berperan pada proses penyembuhan luka melalui mekanisme inflamasi, angiogenesis dan pembentukan matrik pada proses penyembuhan luka. Stres oksidatif dapat dikurangi atau dihambat dengan pemberian antioksidan yang bersifat scavenger terhadap radikal bebas yang ada.

\section{SARAN}

Untuk mengatasi pengaruh stres oksidatif terhadap proses penyembuhan luka perlu pengetahuan yang lebih dalam mengenai bahan lain yang bisa mempunyai efek sebagaian antioksidan seperti Spirulina yang dikatakan mempunyai efek antioksidan dan efek yang lain dan berpengaruh pada proses penyembuhan luka.

\section{DAFTAR PUSTAKA}

1. Luchi, Y., et al, 2010. Spontaneous skin damage and delayed wound healing in SOD1-deficient mice. Mol Cell Biochem. 341; 181-194.

2. Vermeij, W.P., Backendorf, C., 2010. Skin Cornification Proteins Provide Global Link between ROS Detoxification and Cell Migration during Wound Healing. PLOS ONE. 5(8); e11957; 1-7.

3. Valko, M., Leibfritz, D., Moncol, J., Cronin, M.T.D., Mazur, M., Telser, J., 2007. Free radicals and antioxidants in normal physiological functions and human disease. The International Journal of Biochemistry \& Cell Biology. 39 (1); 44-84.

4. Soreja , A., Drews, M., Malinski, T., 2005. Role of nitric oxide, nitroxidative and oxidative stress in wound healing. Pharmacological reports. 57; 108-119.

5. Chiu, J., Dawes, I.W., 2012. Redoxs control of cell proliferation. Trends in Cell Biology. 22 (11); 592-601.

6. Schäfer, M., Werner, S., 2008. Oxidative stress in normal and impaired wound repair. Pharmacological Research. 58 (2); 165-171. 
ISSN 1978-2071 (Print); ISSN 2580-5967 (Online) Jurnal IImiah Kedokteran Wijaya Kusuma 5(2) : 22-29

7. Ardhie, A. M., 2011. Radikal Bebas dan peran Antioksidan dalam Mencegah Penuaan. Medicinus. 24 (1); 4-9.

8. Burton, G. J., Jauniaux, E., 2011. Oxidative stress. Best Practice \& Research Clinical Obstetrics and Gynaecology. 25; 287-298.

9. Madamanchi, N.G., Vendrov, A., Runge, M.S., 2005. Oxidative Stress and Vascular Disease. Arterioscler Thromb Vasc Biol. 25; 29-38.

10. Schremi, S., Szeimies, R. M., Prantl, L., Landthaler, M., Babilas, P., 2010. Oxygen in Acute and Chronic Wound Healing. The British Journal of Dermatology. 163 (2); 257-268.

11. Vogiatzi, G., Tousoulis, D., Stefanadis, C., 2009. The Role of Oxidative Stress in Atherosclerosis. Hellenic J cardiol. 50; 402409.

12. Ushio-Fukai, M., Nakamura, Y., 2008. Reactive oxygen species and angiogenesis: NADPH oxidase as target for cancer therapy. J Cancer Letters. 266; 37-52.

13. Rahman, K., 2007. Studies on free radicals, antioxidants, and co-factors. Clinical Intervention in Aging. 2 (2); 219-236. 